\title{
Intercomparison of clumping index estimates from POLDER, MODIS, and MISR satellite data over reference sites
}

\author{
Jan Pisek ${ }^{\mathrm{a}, *}$, Ajit Govind ${ }^{\mathrm{b}}$, Stefan K. Arndt ${ }^{\mathrm{c}}$, Darren Hocking ${ }^{\mathrm{d}}$, Timothy J. Wardlaw ${ }^{\mathrm{e}}$, Hongliang Fang ${ }^{\mathrm{f}}$, \\ Giorgio Matteucci ${ }^{\mathrm{g}}$, Bernard Longdoz ${ }^{\mathrm{h}}$ \\ a Tartu Observatory, 61602 Tõravere, Tartumaa, Estonia \\ ${ }^{\mathrm{b}}$ INRA, UMR 1391 ISPA, F-33140 Villenave d'Ornon, Bordeaux, France \\ ' Department of Ecosystem and Forest Science, The University of Melbourne, 500 Yarra Boulevard, Richmond, Victoria 3121, Australia \\ ${ }^{\mathrm{d}}$ Monash University, Victoria, Australia \\ ${ }^{\mathrm{e}}$ Forestry Tasmania, Division of Research and Development, GPO Box 207, Hobart, Tasmania 7001, Australia \\ ${ }^{\mathrm{f}}$ LREIS, Institute of Geographic Sciences and Natural Resources Research, CAS, Beijing 100101, China \\ ${ }^{\mathrm{g}}$ Consiglio Nazionale delle Ricerche, Institute of Agro-Environmental and Forest Biology, Rome, Italy \\ ${ }^{\mathrm{h}}$ INRA, UMR Ecologie et Ecophysiologie Forestières, UMR1137, Champenoux F-54280, France
}

\section{A R T I C L E I N F O}

\section{Article history:}

Received 3 October 2014

Received in revised form 14 November 2014

Accepted 19 November 2014

Available online 13 December 2014

\section{Keywords:}

Multi-angle remote sensing

MISR

MODIS

POLDER

Vegetation clumping index

Hotspot

\begin{abstract}
A B S T R A C T
Clumping index is the measure of foliage grouping relative to a random distribution of leaves in space. It is a key structural parameter of plant canopies that influences canopy radiation regimes and controls canopy photosynthesis and other land-atmosphere interactions. The Normalized Difference between Hotspot and Darkspot (NDHD) index has been previously used to retrieve global clumping index maps from POLarization and Directionality of the Earth's Reflectances (POLDER) data at $\sim 6 \mathrm{~km}$ resolution and the Bidirectional Reflectance Distribution Function (BRDF) product from Moderate Resolution Imaging Spectroradiometer (MODIS) at $500 \mathrm{~m}$ resolution. Most recently the algorithm was also applied with Multi-angle Imaging SpectroRadiometer (MISR) data at $275 \mathrm{~m}$ resolution over selected areas. In this study for the first time we characterized and compared the three products over a set of sites representing diverse biomes and different canopy structures. The products were also directly validated with both in-situ vertical profiles and available seasonal trajectories of clumping index over several sites. We demonstrated that the vertical distribution of foliage and especially the effect of understory need to be taken into account while validating foliage clumping products from remote sensing products with values measured in the field. Satellite measurements responded to the structural effects near the top of canopies, while ground measurements may be biased by the lower vegetation layers. Additionally, caution should be taken regarding the misclassification in land cover maps as their errors can propagate into the foliage clumping maps. Our results indicate that MODIS data and MISR data, with $275 \mathrm{~m}$ in particular, can provide good quality clumping index estimates at spatial scales pertinent for modeling local carbon and energy fluxes.
\end{abstract}

(C) 2014 International Society for Photogrammetry and Remote Sensing, Inc. (ISPRS). Published by Elsevier B.V. All rights reserved.

\section{Introduction}

Leaves in canopies are generally grouped into various subcanopy structures such as tree crowns, branches and shoots. These structures make the leaf spatial distribution non-random. The foliage clumping index $(\mathrm{CI})$ is used to quantify the degree of deviation of this distribution from the random case (Chen and Black, 1992; Nilson, 1971). A CI value $>1$ implies that the foliage is regularly

\footnotetext{
* Corresponding author.

E-mail address: janpisek@gmail.com (J. Pisek).
}

distributed; $\mathrm{a} \mathrm{CI}=1 \mathrm{a}$ random distribution and if $\mathrm{CI}<1$ the foliage is more clumped than random (Chen et al., 2005; or see e.g. Chen, 1996 for in-depth discussion). The $\mathrm{CI}$ is an important parameter for the correct assessment of true leaf area index $\left(L_{-} t\right)$ from usually measured effective leaf area index $\left(L \_e ; L_{-} t=L_{-} e / C I\right.$; Chen, 1996), and is also required for estimation of sunlit and shaded leaf fractions in the canopy (Govind et al., 2013) and for accurate modeling of the canopy-level gross primary production (GPP) (Baldocchi and Harley, 1995; Ryu et al., 2011). Chen et al. (2012) recently showed that global GPP can be overestimated by as much as $12 \%$ even when accurate $L_{-} t$ is available but clumping is ignored. 
The CI can vary considerably even within a particular land cover type (Pisek et al., 2011a), and it is highly desirable to map the spatial distribution of this index using remote sensing data (Chen et al., 2003). Previous studies (Chen et al., 1999; Lacaze et al., 2002) have shown that directional reflectance has a potential to estimate CI. Sensors such as POLarization and Directionality of the Earth's Reflectances (POLDER; Deschamps et al., 1994; Lier and Bach, 2008) and Multi-angle Imaging SpectroRadiometer (MISR; Diner et al., 2002) are especially well suited for this purpose because they can acquire surface reflectances at multiple view angles of the same ground position on one orbit. POLDER is best used at the global scale because of its $\sim 6 \mathrm{~km}$ nadir resolution and high angular resolution while MISR can be used at both global and regional scales with its $275 \mathrm{~m}$ resolution. In turn, Moderate Resolution Imaging Spectroradiometer (MODIS) at $500 \mathrm{~m}$ resolution currently provides the finest pseudo multi-angular data for the global land surface (Schaaf et al., 2002).

In this study we compared the most recent $\mathrm{CI}$ products from the respective sensors (POLDER - Pisek et al., 2010a; MODIS - He et al., 2012; MISR - Pisek et al., 2013). The evaluation of temporal and spatial consistency between the products was assessed by using (a) selection of sites representing the global distribution of biomes, (b) a set of sites with vertical profiles of clumping, and (c) sites with available $\mathrm{CI}$ estimates covering a complete seasonal cycle.

\section{Materials and methods}

\subsection{Foliage clumping estimates from remote sensing data}

The main characteristics of the three most recent clumping products from the different multi-angle sensors investigated in this work are listed in Table 1 . The $\mathrm{CI}$ can be estimated by using multiangular remote sensing data because the variabilities in reflectances for different sun-sensor configurations contain information about the canopy structure (Goel, 1988; Li et al., 1995). The hotspot, where sun and view geometry coincide, and the darkspot, where the reflectance is at its minimum, form the basis of retrieving the clumping index from the angular signature in all three products. The Normalized Difference Hotspot-Darkspot (NDHD) index either in the red or in the near-infrared (NIR) band is linearly related to clumping index (Chen et al., 2003):

$\mathrm{CI}=A(\mathrm{NDHD})+B$

where $A$ and $B$ are coefficients determined by the linear regression, based on a set of model simulations made with the 4-scale model in Chen et al. (2005). The coefficients vary with solar zenith angle and assumed crown shape (see Table 2 in Chen et al., 2005). The NDHD index is defined as:

$\mathrm{NDHD}=(\mathrm{HS}-\mathrm{DS}) /(\mathrm{HS}+\mathrm{DS})$

where HS and DS are the reflectance at the hotspot and darkspot, respectively. Clumping information is primarily in the darkspot reflectance, which contains a maximum of visible shadows observed in the forward-scattering direction, where the reflectance is minimum (Chen and Leblanc, 1997). Clumped canopies cast darker shadows and decrease the darkspot reflectance (Leblanc et al.,
2005). The hotspot acts as the normalizing factor that should minimize the dependence of the NDHD index on foliage optical properties that are important determinants of bidirectional reflectance (Asner et al., 1998).

\subsection{POLDER data}

The first global CI maps were derived using different generations of POLDER sensors that measure directional and polarized reflectance with an approximately $6 \mathrm{~km}$ nadir resolution (Chen et al., 2005; Pisek et al., 2010a). During a single satellite overpass, a surface target was scanned up to 14 (POLDER 1) or 16 times (POLDER 3) under different viewing angles, which also sampled the principle plane of the BRDF. It therefore provided a direct measure of the hotspot and darkspot for NDHD calculation. The final global CI map from POLDER observations (Pisek et al., 2010a) represents the mean annual clumping values calculated from the successful retrievals of POLDER-1 (October 1996 - June 1997) and POLDER3 (the entire year 2005) (Fig. 1A). Gaps in the global coverage by POLDER observations ( $5 \%$ of vegetated areas, mainly in the tropics due to persistent cloud cover) were filled with mean CI values calculated from the successful retrievals over the same biomes for the dominant land cover types from the GLC2000 map. More details can be found in Pisek et al. (2010a).

\subsection{MODIS data}

He et al. (2012) derived a global CI map at $500 \mathrm{~m}$ resolution using the Bidirectional Reflectance Distribution Function (BRDF) product in 2006 from MODIS (Schaaf et al., 2002). While computing the NDHD using the red band (620-670 nm), He et al. (2012) reported that the hotspot calculated from the MODIS BRDF product was underestimated in comparison with POLDER measurements very near the hotspot. Without correcting the bias in the MODIS data, the MODIS-derived CI could be overestimated. He et al. (2012) developed an approach to correct the MODIS hotspot magnitude with co-registered POLDER-3 data acquired at about the same time. After the MODIS hotspot is corrected and the NDHD is calculated, the coefficients ( $A$ and $B$ ), calculated from the second-order polynomial fit of the tabulated relationship between $\mathrm{CI}$ and NDHD in Chen et al. (2005), were used to derive MODIS CI. He et al. (2012) assigned a single annual CI value, the median from its noisy seasonal trajectory, to each pixel in the map used in this study (Fig. 1B).

\subsection{MISR data}

MISR consists of nine cameras arranged to view along track that acquire image data with nominal view zenith angles relative to the surface reference ellipsoid of $0.0^{\circ}, \pm 26.1^{\circ}, \pm 45.6^{\circ}, \pm 60.0^{\circ}$, and $\pm 70.5^{\circ}$ (forward and aftward of the Terra satellite) in four spectral bands $(446,558,672$, and $866 \mathrm{~nm})$. In the global mode, the $672 \mathrm{~nm}$ (red) band images are acquired with a nominal maximum crosstrack ground spatial resolution of $275 \mathrm{~m}$ in all nine cameras and information from all bands is provided at this resolution in the nadir camera as well (Diner et al.,1998, 2002). Pisek et al. (2013)

Table 1

Characteristics of the foliage clumping products under study.

\begin{tabular}{|c|c|c|c|c|c|c|}
\hline Name & Spatial resolution & Algorithm & Parameterization & Global map & Temporal smoothing & References \\
\hline POLDER & $\sim 6 \mathrm{~km}$ & Model derived NDHD(NIR)-CI relationship & Vegetation type & Yes & No & Pisek et al. (2010a) \\
\hline MODIS & $500 \mathrm{~m}$ & Model derived NDHD(red)-CI relationship & Vegetation type & Yes & Yes & He et al. (2012) \\
\hline MISR & $275 \mathrm{~m}$ & Model derived NDHD(red)-CI relationship & Vegetation type & Possible & No & Pisek et al. (2013) \\
\hline
\end{tabular}


Table 2

Overview of the LPV/VALERI validation sites.

\begin{tabular}{|c|c|c|c|c|c|}
\hline Network & Site & Country & Lat (deg) & Lon (deg) & Land cover \\
\hline LPV & Aek Loba & Indonesia & 2.63 & 99.58 & Palm tree plantation \\
\hline LPV & Albemale & NC, USA & 36 & -78 & ENF \\
\hline LPV & Alpilles2 & France & 43.81 & 4.71 & Crops \\
\hline VALERI & Barrax & Spain & 39.07 & -2.1 & Crops \\
\hline LPV & Bondville & IL, USA & 40.01 & -86.29 & Crops \\
\hline LPV & BOREAS NSA & Canada & 55.87 & -98.48 & ENF \\
\hline LPV & BOREAS SSA BERMS & Canada & 53.65 & -105.32 & ENF \\
\hline LPV & Brasschaat (De Inslag) & Belgium & 51.3 & 4.51 & MF \\
\hline VALERI & Camerons & Australia & -32.6 & 116.25 & EBF \\
\hline VALERI & Chilbolton & UK & 51.16 & -1.43 & Crops and forest \\
\hline VALERI & Concepcion & Chile & -37.47 & -73.47 & MF \\
\hline LPV & Counami & French Guyana & 5.35 & -53.24 & $\mathrm{EBF}$ \\
\hline VALERI & Counami & French Guyana & 5.35 & -53.24 & $\mathrm{EBF}$ \\
\hline VALERI & Demmin & Germany & 53.89 & 13.21 & Crops \\
\hline VALERI & Donga & Benin & 9.77 & 1.78 & Grassland \\
\hline LPV & Flakaliden & Sweden & 64.11 & 19.45 & ENF \\
\hline LPV & Fundulea & Romania & 44.41 & 26.58 & Crops \\
\hline VALERI & Gilching & Germany & 48.08 & 11.32 & Crops and forest \\
\hline VALERI & Gnangara & Australia & -31.53 & 115.88 & $\mathrm{EBF}$ \\
\hline LPV & Gourma & Mali & 15.32 & -1.55 & Grassland \\
\hline LPV & Guanacaste & Costa Rica & 10.87 & -85.66 & Tropical dry forest \\
\hline VALERI & Haouz & Morocco & 31.66 & -7.6 & Crops \\
\hline LPV & Harvard Forest & MA, USA & 42.5393 & -72.1779 & DBF \\
\hline VALERI & Hirsikangas & Finland & 62.64 & 27.01 & ENF \\
\hline VALERI & Hombori & Mali & 15.33 & -1.48 & Grassland \\
\hline VALERI & Hyytiälä & Finland & 61.85 & 24.29 & ENF \\
\hline LPV & Järvselja & Estonia & 58.31 & 27.3 & ENF \\
\hline LPV & Kejimkujik NP & Canada & 44.45 & -65.28 & $\mathrm{MF}$ \\
\hline LPV & Konza Prairie & KS, USA & 39.09 & -96.57 & Crops \\
\hline LPV & Krasnoyarsk & Russia & 57.27 & 91.6 & ENF \\
\hline LPV & Laprida & Argentina & -36.99 & -60.55 & Grassland \\
\hline VALERI & Laprida & Argentina & -36.99 & -60.55 & Grassland \\
\hline VALERI & Larose & Canada & 45.38 & -75.22 & $\mathrm{MF}$ \\
\hline VALERI & Le Larzac & France & 43.9375 & 3.123056 & Grassland \\
\hline LPV & Los Inocentes & Costa Rica & 11.01 & -85.49 & Tropical moist forest \\
\hline LPV & Maun & Botswana & -19.92 & 23.59 & Herbaceous \\
\hline LPV & Metolius (old pine) & OR, USA & 44.49 & -121.62 & ENF \\
\hline LPV & Metolius (young pine) & OR, USA & 44.43 & -121.56 & ENF \\
\hline LPV & Mongu & Zambia & -15.44 & 23.25 & Shrubs \\
\hline LPV & Nezer & France & 44.57 & -1.04 & ENF \\
\hline LPV & Okwa River & Botswana & -22.41 & 21.71 & Shrubs \\
\hline LPV & Park Falls & WI, USA & 45.946 & -90.272 & ENF \\
\hline VALERI & Plan De Dieu & France & 44.2 & 4.95 & Crops \\
\hline LPV & Puechabon & France & 43.72 & 3.65 & $\mathrm{EBF}$ \\
\hline LPV & Romilly-sur-Seine & France & 48.44 & 3.77 & Crops \\
\hline VALERI & Rovaniemi & Finland & 66.46 & 25.35 & ENF \\
\hline LPV & Ruokolahti & Finland & 61.53 & 28.71 & ENF \\
\hline LPV & Sevilleta & NM, USA & 34.35 & -106.69 & Shrubs \\
\hline LPV & Siera Chincua & Mexico & 19.82 & -100.28 & ENF \\
\hline VALERI & Siera Chincua & Mexico & 19.82 & -100.28 & ENF \\
\hline LPV & Skukuza & South Africa & -25.02 & 31.497 & Shrubland/woodland \\
\hline VALERI & Sonian & Belgium & 50.77 & 4.41 & ENF \\
\hline VALERI & Sud-Ouest & France & 43.51 & 1.24 & Crops \\
\hline LPV & Tapajos & Brazil & -2.857 & -54.959 & EBF \\
\hline LPV & Ticino & Italy & 45.201 & 9.058 & Poplar plantation \\
\hline LPV & Tshane & Botswana & -24.16 & 21.89 & Herbaceous \\
\hline LPV & Turco & Bolivia & -18.24 & -68.18 & Shrubs \\
\hline VALERI & Wankama & Niger & 13.65 & 2.64 & Grassland \\
\hline LPV & Watson Lake & YK, Canada & 60.09 & -129.38 & MF \\
\hline LPV & Whitecourt & AB, Canada & 54.03 & -115.78 & MF \\
\hline VALERI & Zhang Bei & China & 41.28 & 114.69 & Grassland \\
\hline
\end{tabular}

used the $275 \mathrm{~m}$ resolution data to obtain surface bidirectional reflectance factors (BRFs). The Rahman-Pinty-Verstraete (RPV) model (Rahman et al., 1993) was inverted against these fullresolution BRF values in the red band. The initial hotspot (HS) and darkspot (DS) values in the principal plane were reconstructed for solar zenith angle of $60^{\circ}$ using the four kernel coefficients for a given pixel from the RPV model inversion. Because the MISR-hotspot might still be underestimated due to original data acquisition away from the principal plane, the same hotspot correction of He et al. (2012) as in case of MODIS is applied for MISR data as well. Using the above described approach, seasonal time series of $\mathrm{CI}$ can be reconstructed from the available MISR observations for a given location.

\section{Methodology}

The intercomparison procedure was defined to comply as much as possible with the best practices proposed by the CEOS WGCV LPV subgroup (Garrigues et al., 2008; Baret et al., 2009). It corresponds to Stage 1 validation as defined by the CEOS (Nightingale 

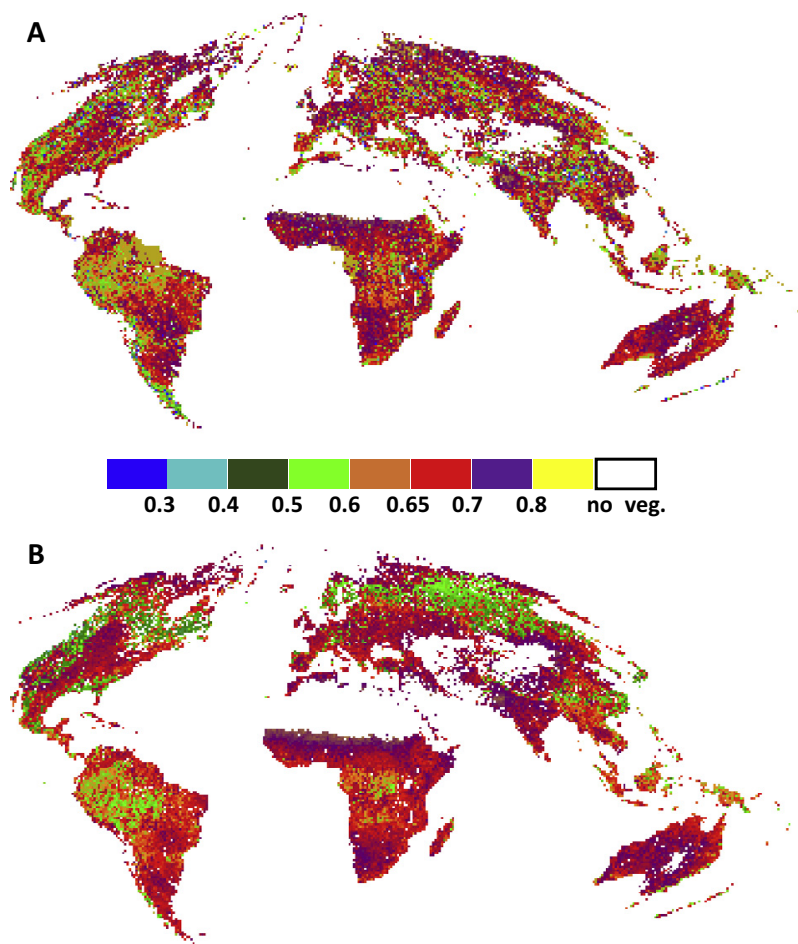

Fig. 1. Global maps of foliage clumping from POLDER (A) and MODIS (B).

et al., 2011; Weiss et al., 2014). First we evaluated the consistency of the CI products over selected locations (Section 3.1.). Next, individual product accuracy was assessed using a small set $(<30)$ of locations by comparison with reference in situ data (Section 3.2). We concluded with an assessment of how well the products compare with the temporal changes in clumping over a subset sites with available in situ temporal profiles of CI (Section 3.2.2).

\subsection{Pair-wise comparison over LPV/VALERI sites}

First we retrieved $\mathrm{CI}$ values from the corresponding products over a set of 63 globally distributed Land Product Validation (LPV) and VAlidation of Land European Remote sensing Instruments (VALERI) sites (Table 2) that represent a recommended pool of sites for the systematic intercomparison of land biophysical products (Baret et al., 2006; Garrigues et al., 2008; Nightingale et al., 2011). For analysis requiring direct product-to-product comparison, the common approach is to resample them to $3 \times 3$ pixel size to reduce effects from co-registration inaccuracies and Point Spread Function differences (see e.g. Camacho et al., 2013; D'Odorico et al., 2014). However, here intercompared products contain clumping retrievals at very different spatial scales, ranging from $275 \mathrm{~m}$ (MISR) to $\sim 6 \mathrm{~km}$ (POLDER). Further resampling to $3 \times 3$ pixel size would produce values at a scale $(\sim 18 \mathrm{~km})$ with very little meaningful information. Additionally, a single $\mathrm{CI}$ value was assigned to each pixel in global POLDER (Pisek et al., 2010a) and MODIS maps (He et al., 2012), while MISR results have been presented so far in the form of temporal trajectories over selected areas, where temporal resolution varied based on the availability of good quality remote sensing data (Pisek et al., 2013). The intercomparison retrievals were thus simply centered over each validation site. MISR retrievals were made using the closest in time available good quality MISR BRF data to the date of ground measurements of biophysical parameters at each site. Given the fact that all three products used the identical NDHD-CI algorithm by Chen et al.
(2005) and MODIS and POLDER maps are already in the same (inverted sinusoidal) projection, the differences between the individual products should highlight mainly the changes in vegetation heterogeneity with spatial scale. The consistency is further evaluated by intercomparing the bulk distribution of the available global product values per biome type.

\subsection{Comparing clumping products with in situ measurements}

The $\mathrm{CI}$ products were validated over an additional global validation dataset with measured vertical or temporal profiles of foliage clumping from Pisek et al. (2013) that was further expanded with additional sites to represent all the main biomes. Detailed site descriptions are provided in Table 3. The methodology to obtain in situ CI estimates has been previously described in detail in Pisek et al. (2013). The field data should be optimally integrated with high resolution imagery to allow a real product validation (Morisette et al., 2006). Unfortunately, with only one exception of a limited extent high resolution map of clumping index $\left(<1 \mathrm{~km}^{2}\right)$ by Simic et al. (2010), no such maps are currently available, allowing only a limited evaluation. Due to the current absence of high-resolution $\mathrm{CI}$ maps, the remote sensing retrievals were simply centered over each validation site similarly to what was done in the previous Section 3.1.

\subsubsection{Vertical profiles of clumping index}

In-situ measurements of CI at different heights using towers were available for twelve of the field sites. We measured two northern boreal evergreen needleleaf stands in Hyytiälä $\left(61.85^{\circ}\right.$ $\left.\mathrm{N}, 24.29^{\circ} \mathrm{E}\right)$ and Sodankylä $\left(67.36^{\circ} \mathrm{N}, 26.64^{\circ} \mathrm{E}\right)$, Finland. Scots pine (Pinus sylvestris L.) was dominant in both stands. The forest floor vegetation in Hyytiälä was dominated by lingonberry, blueberry, lichens and mosses (Ilvesniemi et al., 2009) and by fork moss with lichens at Sodankylä (Manninen et al., 2012). The third boreal evergreen needleleaf stand was near Sudbury, Canada $\left(47.16^{\circ} \mathrm{N}, 81.75^{\circ}\right.$ $\mathrm{W})$. The overstory vegetation was formed by short black spruce (Picea mariana) trees $(\sim 5.6 \mathrm{~m})$; the understory vegetation consisted mainly of feather moss (Hylocomium splendens) with contributions from labrador tea (Ledum groenlandicum) and leather leaf (Chamaedaphne calyculata) (Pisek et al., 2010b). All three boreal forest sites lacked a tall understory vegetation.

The understory was also virtually missing at the three evergreen broadleaf forest sites. The Mediteranean oak (Quercus ilex) stand in Castelporziano, Italy $\left(41.71^{\circ} \mathrm{S} \mathrm{N}, 12.38^{\circ} \mathrm{E}\right)$ contained only a few Pistacia lentiscus bushes in the understory layer. The Wombat forest research site $\left(-37.42^{\circ} \mathrm{S}, 144.09^{\circ} \mathrm{E}\right)$ is located in the Wombat State Forest, Victoria, SE Australia. The site is a secondary regrowth Eucalypti forest that was last harvested in 1980. Dominant tree species are Messmate Stringybark (Eucalyptus obliqua), Narrow Leaf Peppermint (Eucalyptus radiata) and Candlebark (Eucalyptus rubida) with an average canopy height of $25 \mathrm{~m}$. The understory consists mainly of patchy grasses. The second dry sclerophyll site at Whroo $\left(-36.67^{\circ} \mathrm{S}, 145.03^{\circ} \mathrm{E}\right)$ in Victoria, Australia is box ironbark woodland with lower tree height and canopy cover. The vegetation was dominated by two main Eucalypt species: Gray Box (Eucalyptus microcarpa) and Yellow Gum (Eucalyptus leucoxylon). The mean tree height at Whroo was $15.3 \pm 0.2 \mathrm{~m}$.

Warra Long Term Ecological Research (LTER) site $\left(-43.09^{\circ} \mathrm{S}\right.$, $146.66^{\circ} \mathrm{E}$; Neyland et al., 2000) is located in SW Tasmania, Australia. It represents a tall E. obliqua wet forest with rainforest understory and a dense man-fern (Dicksonia antarctica) ground-layer. The forests around the Warra site had mature heights in excess of $55 \mathrm{~m}$ : the tallest E. obliqua within the LTER reaches a height of $90 \mathrm{~m}$.

Two native cloud rainforest stands were located in Thurston Lava Tube $\left(19.41^{\circ} \mathrm{N}, 155.23^{\circ} \mathrm{W}\right)$ and Laupahoehoe $\left(19.93^{\circ} \mathrm{N}\right.$, $\left.155.29^{\circ} \mathrm{W}\right)$, Hawai'i, USA. The Thurston Lava Tube site consists 
Table 3

Characteristics of the validation sites with vertical or seasonal profiles of clumping.

\begin{tabular}{|c|c|c|c|c|c|c|c|c|c|}
\hline Site & Location & Lat & Lon & $\begin{array}{l}\text { Forest } \\
\text { type }\end{array}$ & Overstory & $\begin{array}{l}\text { Mean } \\
\text { tree } \\
\text { height } \\
(\mathrm{m})\end{array}$ & Understory & Reference & $\begin{array}{l}\text { In-situ } \\
\text { data } \\
\text { collection }\end{array}$ \\
\hline Hyytiälä & Finland & 61.85 & 24.29 & NEF & SP & 16 & Lingonberry, blueberry and mosses & $\begin{array}{l}\text { Ilvesniemi } \\
\text { et al. (2009) }\end{array}$ & $2001 / 11$ \\
\hline Sodankylä & Finland & 67.36 & 26.64 & $\mathrm{NEF}$ & SP & 12 & Lichen, fork moss & $\begin{array}{l}\text { Rautiainen } \\
\text { et al. (2007) }\end{array}$ & $2007 / 9$ \\
\hline Sudbury & Canada & 47.16 & -81.75 & NEF & BS & 5.6 & Feather moss, labrador and leather tea & $\begin{array}{l}\text { Pisek et al. } \\
\text { (2010b) }\end{array}$ & $2007 / 6$ \\
\hline Laupahoehoe & HI, USA & 19.93 & -155.3 & EBF & $\mathrm{M}, \mathrm{K}$ & 19 & Cibotium spp. & $\begin{array}{l}\text { Kellner and } \\
\text { Asner (2009) }\end{array}$ & $2013 / 1$ \\
\hline $\begin{array}{l}\text { Thurston Lava } \\
\text { Tube }\end{array}$ & HI, USA & 19.41 & -155.2 & EBF & M & $14.5 \pm 1.4$ & Cibotium glaucum $(3.8 \pm 2.7 \mathrm{~m})$ & $\begin{array}{l}\text { Giambelluca } \\
\text { et al.(2009) }\end{array}$ & $2010 / 9$ \\
\hline Castelporziano & Italy & 41.71 & 12.38 & EBF & MEO & 16 & Pistacia lentiscus & $\begin{array}{l}\text { Fares et al. } \\
(2014)\end{array}$ & $2014 / 6$ \\
\hline Wombat & Australia & -37.42 & 144.09 & EBF & $\begin{array}{l}\text { EO, ERa, } \\
\text { ERu }\end{array}$ & 25 & Patchy grass & $\begin{array}{l}\text { Haverd et al. } \\
\text { (2013) }\end{array}$ & $2013 / 7$ \\
\hline Whroo & Australia & -36.67 & 145.03 & EBF & EM, EL & $15.3 \pm 0.2$ & Patchy grass & New site & $2013 / 7$ \\
\hline Warra & Australia & -43.09 & 146.66 & EBF & EO & 55 & $\begin{array}{l}\text { Nothofagus cunninghamii, Atherosperma } \\
\text { moschatum, Eucryphia lucida, Phyllocladus } \\
\text { aspleniifolius }\end{array}$ & $\begin{array}{l}\text { Neyland } \\
\text { et al. (2000) }\end{array}$ & $2013 / 8$ \\
\hline Järvselja & Estonia & 58.27 & 27.27 & MF & $\begin{array}{l}\text { SB, BA, } \\
\text { NS }\end{array}$ & 17 & $\begin{array}{l}\text { Suppressed tree layer (mean height of } \\
6.4 \pm 0.6 \mathrm{~m} \text { ) }\end{array}$ & $\begin{array}{l}\text { Noe et al. } \\
(2011)\end{array}$ & $2011 / 7$ \\
\hline $\begin{array}{l}\text { Morgan- } \\
\text { Monroe } \\
\text { State Forest }\end{array}$ & IN, USA & 39.32 & -86.41 & BDF & $\begin{array}{l}\text { SM, TP, S, } \\
\text { WO, BO }\end{array}$ & 27 & Max. understory height $10 \mathrm{~m}$ & $\begin{array}{l}\text { Oliphant } \\
\text { et al. (2006) }\end{array}$ & $2005 / 6$ \\
\hline Hesse & France & 48.67 & 7.06 & BDF & EB & 22 & & $\begin{array}{l}\text { Longdoz } \\
\text { et al. (2008) }\end{array}$ & $2014 / 8$ \\
\hline Yatir & Israel & 31.35 & 35.03 & NEF & $\mathrm{AP}$ & 8 & Sparse grass (Nov-Apr) & $\begin{array}{l}\text { Sprintsin } \\
\text { et al. (2011) }\end{array}$ & 2005 \\
\hline Tonzi & CA, USA & 38.43 & -121 & $\mathrm{~S}$ & $\mathrm{BlO}, \mathrm{GP}$ & $9.4 \pm 4.3$ & Grass & $\begin{array}{l}\text { Ryu et al. } \\
(2012)\end{array}$ & $\begin{array}{l}2009 / 7- \\
2010 / 3\end{array}$ \\
\hline RAMI pine & Estonia & 58.31 & 27.3 & $\mathrm{NEF}$ & SP & 16 & $\begin{array}{l}\text { Ledum palustre, Eriophorum vaginatum, } \\
\text { continuous Sphagnum ssp. moss layer }\end{array}$ & $\begin{array}{l}\text { Kuusk et al. } \\
\text { (2013) }\end{array}$ & $\begin{array}{l}2011 / 4- \\
10\end{array}$ \\
\hline Honghe & China & $\begin{array}{l}47^{\circ} 39.11^{\prime} \\
\mathrm{N}\end{array}$ & $\begin{array}{l}133^{\circ} 31.31^{\prime} \\
\mathrm{E}\end{array}$ & CRO & & & - & $\begin{array}{l}\text { Fang et al. } \\
(2014)\end{array}$ & $\begin{array}{l}2012 / 6- \\
10\end{array}$ \\
\hline
\end{tabular}

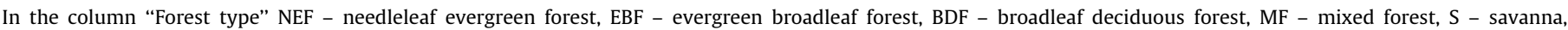

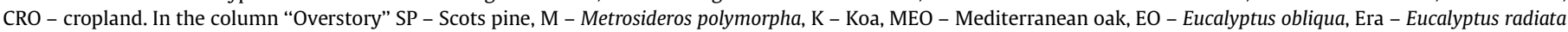

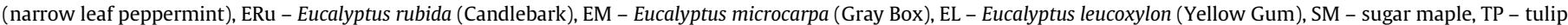

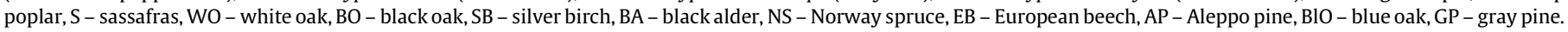

primarily of a single canopy species, ohi'a lehu (Metrosideros polymorpha), with a dense understory layer of hapu'u ferns (Cibotiumspp.) (Giambelluca et al., 2009). Laupahoehoe had similarly comprised overstory with an additional dominant species, Koa (Acacia koa) (Kellner and Asner, 2009).

The successional deciduous broadleaf stand in Morgan-Monroe State Forest $\left(39.32^{\circ} \mathrm{N}, 86.41^{\circ} \mathrm{W}\right)$ in Indiana, USA, was comprised predominantly of sugar maple (Acer saccharum), tulip poplar (Liriodendron tulipifera), sassafras (Sassafras albidum), white oak (Quercus alba), and black oak (Quercus nigra). The canopy vertical structure was fairly consistent around the tower with peaks in $L \_t$ occurring at the crown level at approximately $20-30 \mathrm{~m}$ and at the undergrowth level at approximately $0-10 \mathrm{~m}$ (Oliphant et al., 2004).

The deciduous broadleaf type was also represented by an experimental plot located in the state forest of Hesse $\left(48.67^{\circ} \mathrm{N}, 7.06^{\circ} \mathrm{E}\right)$ in north east of France. The stand was composed mainly (90\%) of European beech (Fagus sylvatica) with a mean tree height $\sim 22 \mathrm{~m}$. Due to canopy closure, understory vegetation is very sparse. Granier et al. (2000) provide a more detailed description of the site.

A scaffolding tower in Järvselja, Estonia $\left(58.27^{\circ} \mathrm{N}, 27.27^{\circ} \mathrm{E}\right)$ was located in a hemiboreal-mixed stand with co-dominant species of silver birch (Betula pendula Roth.), black alder (Alnus glutinosa L.) and Norway spruce (Picea abies (L.) Karst.). A suppressed tree layer (mean height of $6.4 \pm 0.6 \mathrm{~m}$ ) was present around the tower and surrounding forest (Noe et al., 2011).

\subsubsection{Seasonal variation of clumping index}

Seasonal trajectories of $\mathrm{CI}$ were available for four additional sites. Yatir forest, Israel $\left(31.35^{\circ} \mathrm{N}, 35.03^{\circ} \mathrm{E}\right)$, is a monoculture plantation which is dominated by Aleppo pine (Pinus halepensis Mill.). Sparse understory vegetation develops only during the rainy season (November-March) and disappears shortly thereafter (Grünzweig et al., 2003).

An oak-savanna ecosystem in California, USA (Tonzi; $38.43^{\circ} \mathrm{N}$, $120.96^{\circ} \mathrm{W}$ ), was dominated by blue oak trees (Quercus douglasii) with occasional $(<10 \%)$ gray pines (Pinus sabiniana) (Baldocchi et al., 2004).

The third site with a seasonal trajectory of $\mathrm{CI}$ was a Scots pine $\left(P\right.$. sylvestris $L$.) stand in Järvselja, Estonia $\left(58.31^{\circ} \mathrm{N}, 27.30^{\circ} \mathrm{E}\right)$. The site was very homogeneous with respect to its horizontal structure and gap fraction (Pisek et al., 2011b). Forest understory vegetation was composed of sparse labrador tea and cotton grass, and a continuous Sphagnum moss layer. The site is included in the RAdiation transfer Model Intercomparison (RAMI, http:// ramibenchmark.jrc.ec.europa.eu/HTML/Home.php) exercise (Kuusk et al., 2013).

The last validation site representing croplands was located at the Honghe Farm $\left(47.65^{\circ} \mathrm{N}, 133.52^{\circ} \mathrm{E}\right)$ in the Heilongjiang province, NE China. The area was dominated with large homogeneous paddy rice fields ( $>5 \mathrm{~km}^{2}$ homogeneity). The rice-cropping practices were uniform, growing a single rice variety (Japonica) once a year during the summer season (May to September). 

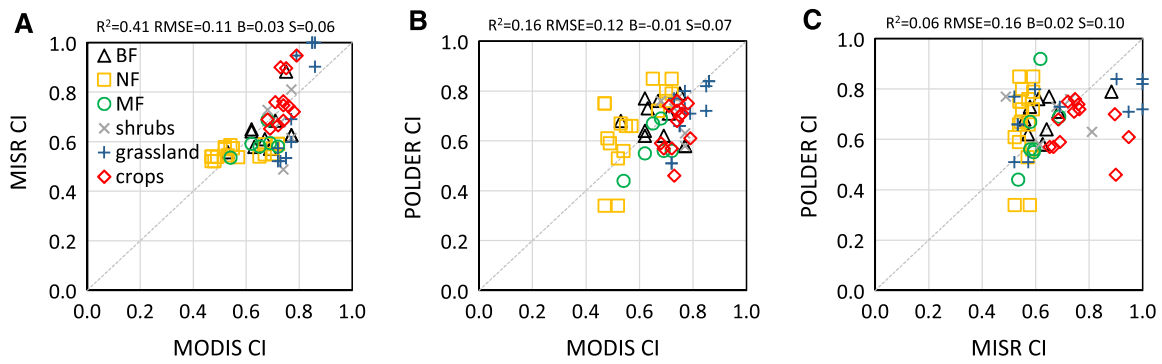

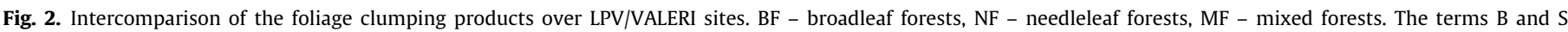
represent the mean and the standard deviation of the difference between the retrievals displayed in the $x$ axis and those shown in the $y$ axis.

Table 4

$\mathrm{CI}$ product characteristics by biome (average statistics calculated over vegetated areas).

\begin{tabular}{|c|c|c|c|c|}
\hline \multirow[t]{2}{*}{ GLCC2000 land cover type } & \multicolumn{2}{|c|}{ Polder-3 } & \multicolumn{2}{|c|}{ MODIS } \\
\hline & Mean & Standev & Mean & Standev \\
\hline Tree cover, broadleaf, evergreen & 0.64 & 0.11 & 0.66 & 0.05 \\
\hline Tree cover, broadleaf, deciduous, closed & 0.69 & 0.08 & 0.7 & 0.04 \\
\hline Tree cover, broadleaf, deciduous, open & 0.72 & 0.05 & 0.72 & 0.03 \\
\hline Tree cover, needleleaf, evergreen & 0.63 & 0.12 & 0.53 & 0.04 \\
\hline Tree cover, needleleaf, deciduous & 0.78 & 0.07 & 0.57 & 0.03 \\
\hline Tree cover, mixed leaf type & 0.72 & 0.11 & 0.69 & 0.04 \\
\hline Tree cover, regularly flooded, fresh water & 0.67 & 0.15 & 0.67 & 0.05 \\
\hline Tree cover, regularly flooded, saline water & 0.78 & 0.17 & 0.71 & 0.06 \\
\hline Mosaic: Tree cover/other natural vegetation & 0.7 & 0.05 & 0.71 & 0.04 \\
\hline Tree cover, burnt & 0.78 & 0.15 & 0.7 & 0.04 \\
\hline Shrub cover, closed-open, evergreen & 0.77 & 0.17 & 0.71 & 0.05 \\
\hline Shrub cover, closed-open, deciduous & 0.74 & 0.09 & 0.74 & 0.04 \\
\hline Herbaceous cover, closed-open & 0.77 & 0.12 & 0.75 & 0.05 \\
\hline Sparse herbaceous or sparse shrub cover & 0.78 & 0.16 & 0.76 & 0.05 \\
\hline Reg. flooded shrub and/or herbaceous cover & 0.8 & 0.14 & 0.73 & 0.04 \\
\hline Cultivated and managed areas & 0.78 & 0.11 & 0.75 & 0.04 \\
\hline Mosaic: cropland/tree cover/natural veg & 0.77 & 0.12 & 0.7 & 0.04 \\
\hline Mosaic: cropland/shrub and/or grass cover & 0.76 & 0.05 & 0.75 & 0.04 \\
\hline
\end{tabular}

\section{Results and discussion}

\subsection{Pair-wise product intercomparison over the LPV/VALERI sites}

The pair-wise comparisons between $\mathrm{CI}$ values from different products centered over the 63 sites from LPV/VALERI networks are shown in Fig. 2. CI values from MODIS and MISR showed the best overall agreement (Fig. 2A). This is not surprising, since the two products use the same wavelength domain (visible red) for the $\mathrm{CI}$ retrieval and they are also the closest in resolution scale ( $500 \mathrm{~m}$ vs. $275 \mathrm{~m}$ ). The relative distribution of CI values between vegetation types coincided between the two products as well. Needleleaf forests are the most clumped vegetation type, followed by mixed and deciduous forests, shrubs and crops, and with grasslands appearing to be the least clumped (closest to the random distribution). The MODIS CI product indicated a much wider $\mathrm{CI}$ range over intercomparison sites with needleleaf forests (0.47-0.72) compared to MISR (0.52-0.59). Depending on the land cover, different coefficients were applied to estimate CI from Eq. (1) (Chen et al., 2005). All MISR retrievals coincided with the LPV/VALERI needleleaf designations over the respective sites. The MODIS CI product uses the GLC2000 land cover map (Bartholomé and Belward, 2005), which can differ from the actual vegetation types present at individual LPV/VALERI sites. He et al. (2012) previously noted that $\mathrm{CI}$ can be seriously biased by using a wrong land cover type. On the contrary, in our study the MISR retrievals varied markedly over grasslands $(0.52-1.0)$, while MODIS retrievals were confined to much narrower range $(0.72-0.86)$. There is no specific algorithm for $\mathrm{CI}$ retrieval over non-forested areas; coefficients for broadleaf trees are applied in the respective products over these areas, instead. The modeled results by Chen et al. (2005) suggested that areas with less than $25 \%$ vegetation coverage or fragmented land cover should be treated with caution. Our results confirm this as well, especially retrievals over non-forested areas should be taken with pre-caution. Interestingly, MODIS and MISR retrievals agree quite well over fields with crops (Fig. 2A), which confirmed similarly homogeneous vegetation coverage at both scales of $275 \mathrm{~m}$ and $500 \mathrm{~m}$ over the majority of the intercomparison sites.

The distribution of $\mathrm{CI}$ values for needleleaf forests was more similar along the 1:1 line in case of the MODIS-POLDER pair-wise comparison (Fig. 2B). This is not surprising, since both products use the same GLC2000 land cover map, and most of the intercomparison sites with forests were located within larger areas with homogeneous vegetation. Fig. 2B also confirmed that using different bands for the CI retrieval (red from MODIS vs. NIR from POLDER) introduced no systematic bias. The POLDER CI product included two clear outliers with very low $\mathrm{CI}$ values (high clumping) (Fig. 2B and C): BOREAS BERMS (0.34) and Watson Lake (0.44). Given the location of the respective sites, such values indicate the effects of topography on CI retrievals from POLDER data had not been entirely removed by Pisek et al. (2010a). The MISRPOLDER comparison offered the least agreement (Fig. 2C). The gradually decreasing agreement between products from Fig. 2A to $C$ confirmed the importance of using $\mathrm{CI}$ value appropriately matched to the scale of the application in question (Ryu et al. 2010).

The mean CI and its one standard deviation for each GLC200 land cover types from the available MODIS and POLDER global CI maps are shown in Table 4. There was not much difference in $\mathrm{CI}$ value distributions from the two maps in Fig. 1 with exception of 

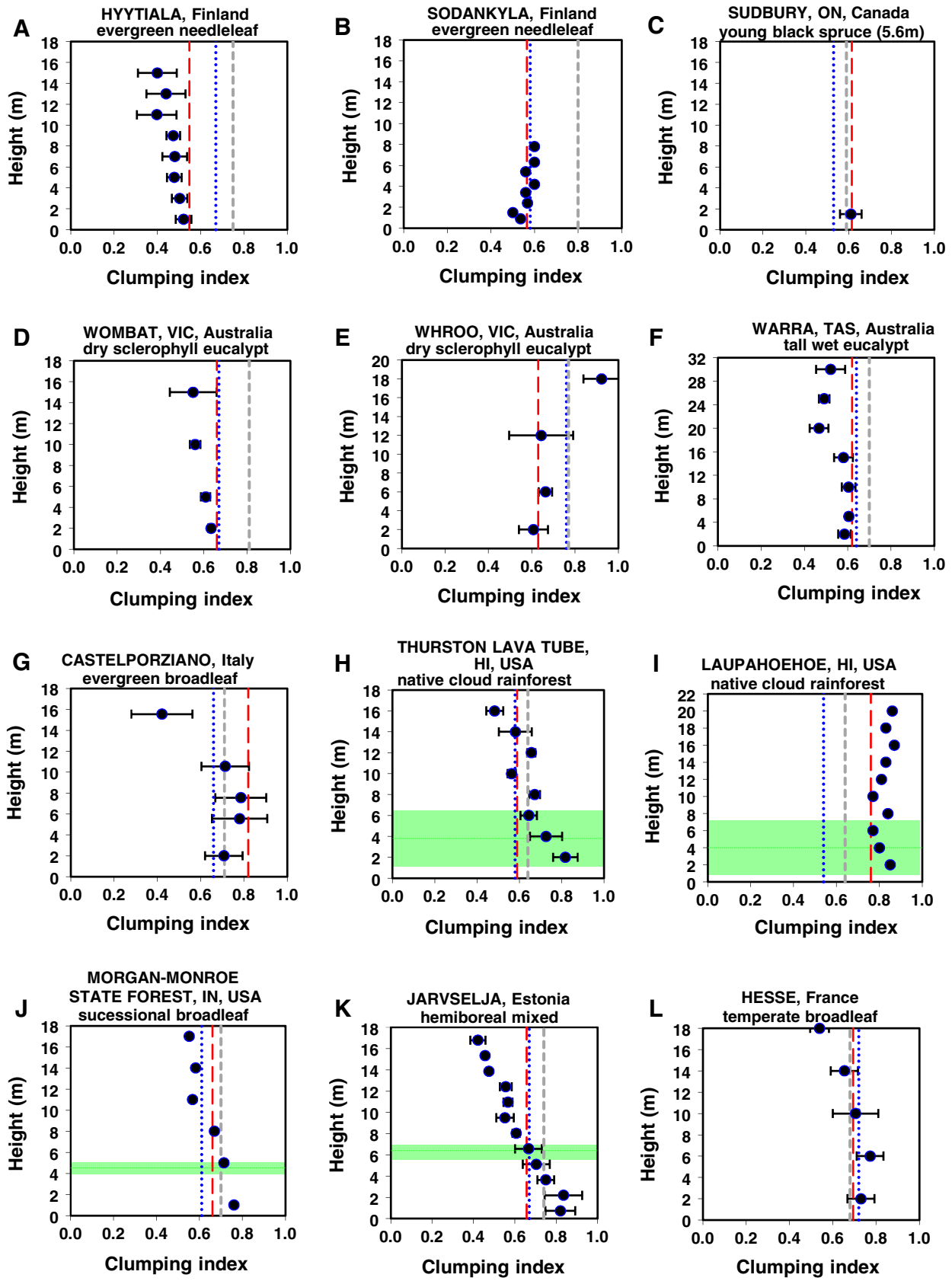

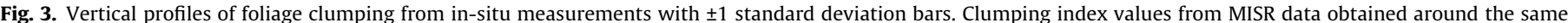

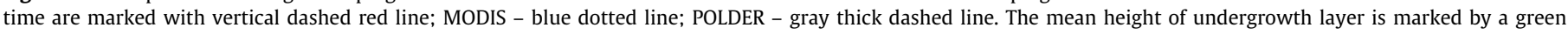

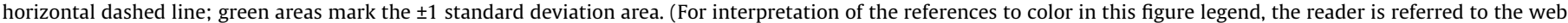
version of this article.)

needleleaf forests, where MODIS CI values appeared to be lower by $\sim 0.1$ than POLDER retrievals. This agreed with the observations from Fig. 2B, suggesting that despite the limited number of intercomparison sites Fig. 2 offered a good initial overview of the differences between the $\mathrm{CI}$ products.

\subsection{Variation of clumping index across canopy depths}

It should be acknowledged that satellite measurements respond primarily to the structural effects in upper levels of canopies. Chen et al. (2005) developed the CI algorithms using $L_{-} t$ input and the resulting gap fraction simulated by the geometrical optical model 4-Scale (Chen and Leblanc, 1997). The CI algorithm should enable the correct retrieval of the stand average clumping of the leaves from remote sensing data. On the other hand ground level CI measurements may be biased by presence of an understory at forest sites, since the two layers can be differently spatially aggregated.

There was no pronounced tree/shrub understory layer at the first three validation sites, representing boreal needleleaf forests (Fig. 3A-C). In situ CI estimates from different heights in the canopy were then very similar, which also confirms previous modeling results by Nilson et al. (2011). The three needleleaf sites with vertical profiles represent forests with different age, height, and species. There was a close agreement of MISR CI retrievals with in situ CI values in all three cases. The MISR CI values also agreed quite well with available in situ measurements over VALERI intercomparison sites (Table 2). This suggests that MISR was indeed capable of producing quality $\mathrm{CI}$ estimates over this vegetation type. 
MODIS CI values were also comparable with in situ measurements over two needleleaf sites with exception of Hyytiälä (Fig. 3A). However, Pisek and Oliphant (2013) previously noted that this disagreement was due to wrongly assigned broadleaf forest GLC2000 land cover type over this site. If the MODIS pixel with the Hyytiälä site was classified correctly as a needleleaf forest, the retrieved MODIS CI value (0.53) agreed well with the $\mathrm{CI}$ measured at the ground (0.52). The differences between assigned land cover types in the GLC2000 map and identified in immediate area around towers in Hyytiälä and Sodankylä (Table 1) also explained the very different POLDER CI values. When the land cover is very homogeneous and matching dominant vegetation type was assigned (Sudbury; Fig. 3C), POLDER CI value was very close to the in situ $\mathrm{CI}$ measurements as well.

Similarly good agreement between ground level in-situ, MISR, and MODIS CI retrievals was observed at eucalypt sites in Australia (Fig. 3D-F). The Whroo tower (Fig. 3E) was located rather close to the edge of the forest - the MISR CI value at $275 \mathrm{~m}$ still picks up the signal from the surrounding forest area, while MODIS and POLDER signals at coarser resolutions are already clearly influenced by the surrounding non-forested (less clumped) area. In the POLDER case such influence was evident over the Wombat site as well (Fig. 3D). Castelporziano represented another validation site without pronounced understory vegetation. The state forest reserve around the tower was large enough to occupy the full footprint of POLDER sensor, and POLDER CI value then offered the best match with the in situ measurements (Fig. 3G).

There was a pronounced understory layer present at the remaining sites with evergreen vegetation and measured vertical profiles of clumping (Fig. 3H-I). The remotely sensed $\mathrm{CI}$ values can then differ from $\mathrm{CI}$ measured at the ground. In the native cloud forests in Hawai'i (Fig. 3H-I), large gaps between tree crowns at upper levels of the canopy may not be measured near the ground due to occlusion by lower vegetation fern branches. Instead, the MISR CI values in particular were close to in situ measurements obtained above the nearly uniform understory fern layer at $\sim 6 \mathrm{~m}$ (Fig. 3H-I). The vertical profile at Thruston Lava Tube site differed from Laupahoehoe because there was an additional dominant species A. koa in the overstory at Thruston Lava Tube. There was a frequent cloud cover over both Hawai'i sites which severely limits the opportunities for acquiring good quality remote sensing data. Due to the missing data, the POLDER CI value (0.64) over the two sites was originally filled and corresponded to mean $\mathrm{CI}$ value calculated from the successful retrievals over the same biome (Pisek et al., 2010a). Such values need to be treated with caution, as they obviously cannot correctly reflect possible local variations in vegetation structure (Fig. 3H-I).

A suppressed tree layer was also present at the two broadleaf stands in Indiana (Fig. 3J) and Estonia (Fig. 3K). The best agreement between satellite and field CI values both at MMSF and in Järvselja was again achieved for observations taken above the understory layer (Fig. 3J-K). Results over Hesse (Fig. 3L) documented that CI retrievals from remote sensing data can match the ground in situ measurements in deciduous broadleaf forests if the land cover vegetation type is correctly assigned, the forest area is sufficiently large, and there is no pronounced shrub/tree understory layer.

\subsection{Seasonal variation of clumping index}

The land surface modeling community has assumed that clumping is constant over seasons (Baldocchi et al., 2002; Houborg et al., 2009; Sampson et al., 2006) and thus its temporal variation has been ignored. Fig. 4 shows the clumping may change with season even for evergreen needleleaf forests due to needle phenology (Sprintsin et al., 2011). At Yatir and Tonzi the POLDER $\mathrm{CI}$ values matched quite well the seasonal clumping minima (Fig. 4A and B). Clumping was underestimated in both maps from POLDER and MODIS over Järvselja RAMI stand (Fig. 4C). Similarly to the Hyytiälä case (Fig. 4A), this disagreement was caused by wrongly assigned forest GLC2000 land cover type over this site (He, pers. comm.). MODIS and POLDER CI values closely matched the in situ measurements in Järvselja RAMI stand after assigning the correct land cover type (needleleaf). The POLDER CI value did not agree with seasonal clumping minima from in situ measurements at Honghe site (Fig. 4D). This was due to insufficient vegetation coverage for correct clumping information retrieval from the satellite data at the beginning and the end of season. MISR CI seasonal minima also leveled off around the same value as POLDER (0.84; Fig. 4D), confirming the effect of insufficient vegetation coverage during the non-growing season at non-evergreen sites. Fig. 4 illustrates the potential of MISR to track successfully the seasonal trajectories of clumping. The retrieved trajectories were also rather stable. No smoothing algorithm was applied within the MISR CI processing chain (Pisek et al., 2013). The stability is not surprising since the primary mission of the MISR instrument was to study the Earth atmosphere and, in particular, to characterize atmospheric aerosols and clouds (Diner et al., 1998; Verstraete et al., 2012). Significant efforts have been invested to address these issues in great detail (Diner et al., 2005) and provide quality Level 2 products that are utilized to convert MISR TOA BRF into surface BRF values at $275 \mathrm{~m}$ resolution. At the same time, the MISR product quality requirements are rigorous (Bothwell et al., 2002), and no good quality Level 2 data may be available for extended periods of time (Fig. 4C and D). Fig. 4C and D demonstrates that gaps in seasonal trajectory of $\mathrm{CI}$ can be effectively filled using MISR observations from other years over sites with stable land cover, when the atmospheric conditions were more favorable.

\section{Conclusion}

In this study we compared the most recent $\mathrm{CI}$ products from the space-borne multi-angular POLDER, MODIS, and MISR sensors for
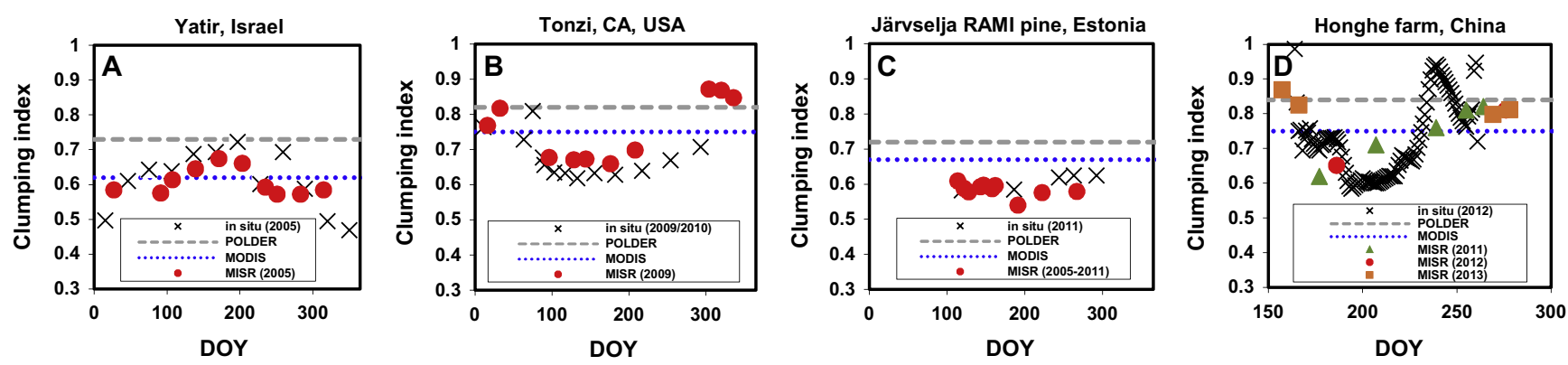

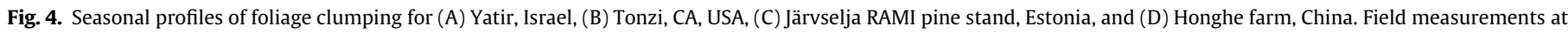
all four sites were taken above ground layer vegetation (if present). 
the first time. This exercise corresponded to Stage 1 validation as defined by CEOS (Nightingale et al., 2011; Weiss et al., 2014). Our main results highlight the following:

(1) Satellite measurements responded to the structural effects near the top, while ground measurements may be biased by the lower vegetation/understory layers.

(2) POLDER CI map (Pisek et al., 2010a) may be used to predict the upper boundary of seasonal clumping. The coarse spatial resolution of the POLDER map at $\sim 6 \mathrm{~km}$ presents the main challenge for the product validation with in situ measurements.

(3) CI values in MODIS global clumping map by He et al. (2012) corresponded to the median $\mathrm{CI}$ from the seasonal trajectories of clumping. The MODIS CI map by He et al. (2012) with its spatial resolution at $500 \mathrm{~m}$ compared to $\sim 6 \mathrm{~km}$ from POLDER might be also more suitable given the spatial resolution of current land surface models (e.g. Houborg et al., 2009).

(4) If more detailed information is required, MISR retrievals can track correctly seasonal developments of clumping as well.

(5) Correct land cover information (deciduous vs. needleleaf) is crucial for retrieving accurate $\mathrm{CI}$ value. Furthermore, spaceborne sensors cannot provide correct $\mathrm{CI}$ estimates over areas with insufficient vegetation coverage $(<25 \%)$.

The field data should be optimally integrated with high resolution imagery to allow a more thorough product validation and intercomparison (Morisette et al., 2006). The current lack of such high resolution $\mathrm{CI}$ maps presents the main challenge for the next, more in-depth validation stages as defined by CEOS. Given the previously documented importance of foliage clumping on correct estimation of global terrestrial gross primary productivity (e.g. Chen et al., 2012; Ryu et al., 2012), production of higher resolution maps of foliage clumping, such as using UAVs equipped with BRF sensors (Kuusk et al., 2014), is strongly encouraged.

\section{Acknowledgements}

Jan Pisek was supported by the funding from the FP7-Marie Curie Actions programme, Estonian Science Foundation Grant nos. ERMOS32 and PUT232. Financial support by the Transnational Access to Research Infrastructures activity in the 7th Framework Programme of the EC under the ExpeER project for conducting the research at Castelporziano and Hesse sites is gratefully acknowledged. The measurements at Wombat, Whroo and Warra in Australia were funded by the Terrestrial Ecosystem Research Network (TERN) Australian Supersite Network, the TERN OzFlux Network, and Australian Research Council (ARC) Grants LE0882936 and DP120101735. Data collection at the Honghe farm was supported by the National Natural Science Foundation of China (41171333). The first author would like to thank Drs. Lola Suarez and Zbynek Malenovsky for their help with transport logistics to Wombat and Whroo sites. We thank two anonymous reviewers for providing comments that helped with improving quality of the original submission. Research and access at the Castelporziano site was granted by the Scientific-Technical Commission (STC) of the Reserve. Activities at the Grotte di Piastra flux tower are partly funded by the STC and are performed in cooperation by CNR, CRA and University of Tuscia. The General Secretariat of the Presidency of the Italian Republic is greatly acknowledged.

\section{References}

Asner, G.P., Braswell, B.H., Schimel, D.S., Wessman, C.A., 1998. Ecological research needs from multiangle remote sensing data. Remote Sens. Environ. 63, 155165.
Baldocchi, D.D., Harley, P.C., 1995. Scaling carbon dioxide and water vapour exchange from leaf to canopy in a deciduous forest. II. Model testing and application. Plant, Cell Environ. 18, 1157-1173.

Baldocchi, D.D., Wilson, K.B., Gu, L.H., 2002. How the environment, canopy structure and canopy physiological functioning influence carbon, water and energy fluxes of a temperate broad-leaved deciduous forest - an assessment with the biophysical model CANOAK. Tree Physiol. 22, 1065-1077.

Baldocchi, D.D., Xu, L.K., Kiang, N., 2004. How plant functional-type, weather, seasonal drought, and soil physical properties alter water and energy fluxes of an oak-grass savanna and an annual grassland. Agric. For. Meteorol. 123, $13-39$.

Baret, F., Morissette, J., Fernandes, R., Champeaux, J.L., Myneni, R., Chen, J., et al., 2006. Evaluation of the representativeness of networks of sites for the global validation and intercomparison of land biophysical products. Proposition of the CEOS-BELMANIP. IEEE Trans. Geosci. Remote Sens. 44, 1794-1803.

Baret, F., Nightingale, J., Garrigues, S., Nickeson, J., 2009. Report on the CEOS Land Product Validation sub-group meeting Missoula, Montana, 15 June 2009. Earth Observer 21, 26-30.

Bartholomé, E., Belward, A.S., 2005. GLC2000: a new approach to global land cover mapping from Earth Observation data. Int. J. Remote Sens. 26, 1959-1977.

Bothwell, G.W., Hansen, E.G., Vargo, R.E., Miller, K.C., 2002. The Multiangle Imaging SpectroRadiometer science data system, its products, tools and performance. IEEE Trans. Geosci. Remote Sens. 40, 1467-1476.

Camacho, F., Cernicharo, J., Lacaze, R., Baret, F., Weiss, M., 2013. GEOV1: LAI, FAPAR essential climate variables and FCOVER global time-series capitalizing over existing products. Part 2: Validation and intercomparison with reference products. Remote Sens. Environ. 37, 310-329.

Chen, J.M., 1996. Optically-based methods for measuring seasonal variation of leaf area index in boreal conifer stands. Agric. For. Meteorol. 80, 135-163.

Chen, J.M., Black, T.A., 1992. Foliage area and architecture of plant canopies from sunfleck size distributions. Agric. For. Meteorol. 60, 249-266.

Chen, J.M., Leblanc, S.G., 1997. A four-scale bidirectional reflectance model based on canopy architecture. IEEE Trans. Geosci. Remote Sens. 35, 1316-1337.

Chen, J.M., Leblanc, S.G., Miller, J.R., Freemantle, J., Loechel, S.E., Walthall, C.L., et al., 1999. Compact Airborne Spectrographic Imager (CASI) used for mapping biophysical parameters of boreal forests. J. Geophys. Res. 104, 27945-27958.

Chen, J.M., Liu, J., Leblanc, S.G., Lacaze, R., Roujean, J.L., 2003. Multi-angular optical remote sensing for assessing vegetation structure and carbon absorption. Remote Sens. Environ. 84, 516-525.

Chen, J.M., Menges, C.H., Leblanc, S.G., 2005. Global mapping of foliage clumping index using multi-angular satellite data. Remote Sens. Environ. 97, 447-457.

Chen, J.M., Mo, G., Pisek, J., Deng, F., Ishozawa, M., Chan, D., 2012. Foliage clumping index as an important structural parameter for estimating global terrestrial gross primary productivity. Global Biogeochem. Cycles 26. http://dx.doi.org/ 10.1029/2010GB003996 (GB1019).

Deschamps, P.Y., Breon, F.M., Leroy, M., Podaire, A., Bricaud, A., Buriez, J.C., Seze, G., 1994. The POLDER mission: instrument characteristics and scientific objectives. IEEE Trans. Geosci. Remote Sens. 32, 598-615.

Diner, D.J., Beckert, J.C., Reilly, T.H., Bruegge, C.J., Conel, J.E., Kahn, R.A., et al., 1998. Multiangle Imaging SpectroRadiometer (MISR) instrument description and experiment overview. IEEE Trans. Geosci. Remote Sens. 36, 1072-1087.

Diner, D.J., Beckert, J.C., Bothwell, G.W., Rodriguez, J.I., 2002. Performance of the MISR instrument during its first 20 months in Earth orbit. IEEE Trans. Geosci. Remote Sens. 40, 1449-1466.

Diner, D.J., Braswell, B.H., Davies, R., Gobron, N., Hu, J., Jin, Y., et al., 2005. The value of multiangle measurements for retrieving structurally and radiatively consistent properties of clouds, aerosols, and surfaces. Remote Sens. Environ. 97, 495-518.

D’Odorico, P., Gonsamo, A., Pinty, B., Gobron, N., Coops, N., Mendez, E., Schaepman, M.E., 2014. Intercomparison of fraction of absorbed photosynthetically active radiation products derived from satellite data over Europe. Remote Sens. Environ. 142, 141-154.

Fang, H., Li, W., Wei, S., Jiang, C., 2014. Seasonal variation of leaf area index (LAI) over paddy rice fields in NE China: intercomparison of destructive sampling, LAI-2200, digital hemispherical photography (DHP), and AccuPAR methods. Agric. For. Meteorol. 198-199, 126-141. http://dx.doi.org/10.1016/ j.agrformet.2014.08.005.

Fares, S., Savi, F., Muller, J., Matteucci, G., Paoletti, E., 2014. Simultaneous measurements of above and below canopy ozone fluxes help partitioning ozone deposition between its various sinks in a Mediterranean Oak Forest. Agric. For. Meteorol. 198-199, 181-191.

Garrigues, S., Lacaze, R., Baret, F., Morisette, J.T., Weiss, M., Nickeson, J.E., et al., 2008. Validation and intercomparison of global leaf area index products derived from remote sensing data. J. Geophys. Res. 113. http://dx.doi.org/10.1029/ 2007JG000635 (G02028).

Giambelluca, T.W., Martin, R.E., Asner, G.P., Huang, M., Mudd, R.G., Nullet, M.A., DeLayä, K., Foot, D., 2009. Evapotranspiration and energy balance of native wet montane cloud forest in Hawaii. Agric. For. Meteorol. 149, 230-243.

Goel, N.S., 1988. Models of vegetation canopy reflectance and their use in estimation of biophysical parameters from reflectance data. Remote Sens. Rev. 4, 1-212.

Govind, A., Guyon, D., Roujean, J.L., Yauschew-Raguenes, N., Kumari, J., Pisek, J. et al., 2013. Effects of canopy architectural parameterizations on the modeling of radiative transfer mechanism. Ecol. Model. 251, 114-126.

Granier, A., Biron, P., Lemoine, D., 2000. Water balance, transpiration and canopy conductance in two beech stands. Agric. For. Meteorol. 100, 291-308. 
Grünzweig, J.M., Lin, T., Schwartz, A., Yakir, D., 2003. Carbon sequestration in aridland forest. Glob. Change Biol. 9, 791-799.

Haverd, V., Raupach, M.R., Briggs, P.R., Canadell, J.G., Isaac, P., Pickett-Heaps, C., et al., 2013. Multiple observation types reduce uncertainty in Australia's terrestrial carbon and water cycles. Biogeosciences 10, 2011-2040.

He, L., Chen, J.M., Pisek, J., Schaaf, C.B., Strahler, A.H., 2012. Global clumping index map derived from the MODIS BRDF product. Remote Sens. Environ. 119, 118130

Houborg, R., Anderson, M.C., Norman, J.M., Wilson, T., Meyers, T., 2009. Intercomparison of a 'bottom-up' and 'top-down' modeling paradigm for estimating carbon and energy fluxes over a variety of vegetative regimes across the U.S. Agric. For. Meteorol. 149, 1875-1895.

Ilvesniemi, H., Levula, J., Ojansuu, R., Kolari, P., Kulmala, L., Pumpanen, J., Launiainen, S., Vesala, T., Nikinmaa, E., 2009. Long-term measurements of the carbon balance of a boreal Scots pine dominated forest ecosystem. Boreal Environ. Res. 14, 731-753.

Kellner, J.R., Asner, G.P., 2009. Convergent structural responses of tropical forests to diverse disturbance regimes. Ecol. Lett. 12, 887-897.

Kuusk, A., Lang, M., Kuusk, J., 2013. Database of optical and structural data for the validation of forest radiative transfer models. In: Kokhanovsky, A.A. (Ed.), Radiative Transfer and Optical Properties of Atmosphere and Underlying Surface. Light Scattering Reviews 7. Springer, Berlin, Germany, pp. 109-148.

Kuusk, A., Kuusk, J., Lang, M., 2014. Directional properties of forest reflectance: measurements and modeling. Agric. For. Meteorol. 185, 14-19.

Lacaze, R., Chen, J.M., Roujean, J.L., Leblanc, S.G., 2002. Retrieval of vegetation clumping index using hotspot signatures measured by the POLDER instrument. Remote Sens. Environ. 79, 84-95.

Leblanc, S.G., Chen, J.M., White, H.P., Latifovic, R., Lacaze, R., Roujean, J.L., 2005. Canada-wide foliage clumping index mapping from multiangular POLDER measurements. Can. J. Remote Sens. 31, 364-376.

Li, X., Strahler, A.H., Woodcock, C.E., 1995. A hybrid geometric optical-radiative transfer approach for modeling albedo and directional reflectance of discontinuous canopies. IEEE Trans. Geosci. Remote Sens. 33, 466-480.

Lier, P., Bach, M., 2008. PARASOL a microsatellite in the A-Train for Earth atmospheric observations. Acta Astronaut. 62 (2-3), 257-263.

Longdoz, B., Gross, P., Granier, A., 2008. Multiple quality tests for analysing $\mathrm{CO}_{2}$ fluxes in a beech temperate forest. Biogeosciences 5, 719-729.

Manninen, T., Korhonen, L., Riihelä, A., Lahtinen, P., Stenberg, P., Roujean, J.-L., Hautecoeur, O., 2012. Boreal forest albedo and LAI in SNORTEX 2008-2010. In: Proceedings of International Geoscience and Remote Sensing Symposium 2012 (IGARSS 2012), pp. 3335-3338.

Morisette, J.T., Baret, F., Privette, J.L., Myneni, R.B., Nickeson, J.E., Garrigues, S., et al., 2006. Validation of global moderate resolution LAI products: a framework proposed within the CEOS Land Product Validation subgroup. IEEE Trans. Geosci. Remote Sens. 44, 1804-1817.

Neyland, M.G., Brown, M.J., Su, W., 2000. Assessing the representativeness of longterm ecological research sites: a case study at Warra in Tasmania. Aust. Forest. 63, 194-198.

Nightingale, J., Schaepman-Strub, G., Nickeson, J., Leads, L.F.A., 2011. Assessing satellite-derived land product quality for earth system science applications: overview of the CEOS LPV sub-group. In: Proceedings of the 34th International Symposium on Remote Sensing of Environment. Sydney, NSW, Australia, 10-15 April 2011.

Nilson, T., 1971. A theoretical analysis of the frequency of gaps in plant stands. Agric. Meteorol. 8, 25-38.

Nilson, T., Kuusk, A., Lang, M., Pisek, J., Kodar, A., 2011. Simulation of statistical characteristics of gap distribution in forest stands. Agr. Forest Meteorol. 151, 895-905.

Noe, S.M., Kimmel, V., Hüve, K., Copolovici, L., Portillo-Estrada, M., Püttsepp, Ü., Jõgiste, K., et al., 2011. Ecosystem-scale biosphere-atmosphere interactions of a hemiboreal mixed forest stand at Järvselja, Estonia. For. Ecol. Manage. 262, 71 81.

Oliphant, A.J., Grimmond, C.S.B., Zutter, H.N., Schmid, H.P., Su, H.B., Scott, S.L., Offerle, B., Randolph, J.C., Ehman, J., 2004. Heat storage and energy balance fluxes for a temperate deciduous forest. Agric. For. Meteorol. 126, 185-201.
Oliphant, A.J., Rose III, J.W., Grimmond, C.S.B., Schmid, H.-P., 2006. Observations of Canopy Light Penetration and Net Ecosystem Exchange of $\mathrm{CO}_{2}$ under different sky conditions in a Mid-Western Mixed Deciduous Forest. In: Proceedings of 27th Conference on Agricultural and Forest Meteorology, American Meteorological Society, San Diego, 5.7.

Pisek, J., Oliphant, A.J., 2013. A note on the height variation of foliage clumping: comparison with remote sensing retrievals. Remote Sens. Lett. 4, 400-408.

Pisek, J., Chen, J.M., Lacaze, R., Sonnentag, O., Alikas, K., 2010a. Expanding global mapping of the foliage clumping index with multi-angular POLDER 3 measurements: evaluation and topographic compensation. ISPRS J. Photogramm. Remote Sens. 65, 341-346.

Pisek, J., Chen, J.M., Miller, J.R., Freemantle, J.R., Peltoniemi, J.I., Simic, A., 2010b. Mapping forest background reflectance in a boreal region using multiangle compact airborne spectrographic imager data. IEEE Trans. Geosci. Remote Sens. 48, 499-510.

Pisek, J., Chen, J.M., Nilson, T., 2011a. Estimation of vegetation clumping index using MODIS BRDF data. Int. J. Remote Sens. 32, 2645-2657.

Pisek, J., Lang, M., Nilson, T., Korhonen, L., Karu, H., 2011b. Comparison of methods for measuring gap size distribution and canopy nonrandomness at Järvselja RAMI (RAdiation transfer Model Intercomparison) test sites. Agric. For Meteorol. 151, 365-377.

Pisek, J., Ryu, Y., Sprintsin, M., He, L., Oliphant, A.J., Korhonen, L., Kuusk, J., Kuusk, A. Bergstrom, R., Verrelst, J., et al., 2013. Retrieving vegetation clumping index from Multi-angle Imaging SpectroRadiometer (MISR) data at $275 \mathrm{~m}$ resolution. Remote Sens. Environ. 138, 126-133.

Rahman, H., Pinty, B., Verstraete, M.M., 1993. Coupled surface-atmosphere reflectance (CSAR) model.2. Semiempirical surface model usable with NOAA Advanced Very High Resolution Radiometer data. J. Geophys. Res. 98, 2079120801.

Rautiainen, M., Suomalainen, J., Mõttus, M., Stenberg, P., Voipio, P., Peltoniemi, J., et al., 2007. Coupling forest canopy and understory reflectance in the Arctic latitudes of Finland, Remote Sens. Environ. 110, 332-343.

Ryu, Y., Nilson, T., Kobayashi, H., Sonnentag O., Law, B.E., Baldocchi, D.D., 2010. On the correct estimation of effective leaf area index: does it reveal information on clumping effects? Agric. For. Meteorol. 150, 463-472.

Ryu, Y., Baldocchi, D.D., Kobayashi, H., van Ingen, C., Li, J., Black, T.A., et al., 2011. Integration of MODIS land and atmosphere products with a coupled-process model to estimate gross primary productivity and evapotranspiration from $1 \mathrm{~km}$ to global scales. Global Biogeochem. Cycles 25. http://dx.doi.org/10.1029/ 2011GB004053 (GB4017).

Ryu, Y., Verfaillie, J., Macfarlane, C., Kobayashi, H., Sonnentag, O., Vargas, R., Ma, S. Baldocchi, D.D., 2012. Continuous observation of tree leaf area index at ecosystem scale using upward-pointing digital cameras. Remote Sens. Environ. 126, 116-125.

Sampson, D.A., Janssens, I.A., Ceulemans, R., 2006. Under-story contributions to stand level GPP using the process model SECRETS. Agric. For. Meteorol. 139, 94 104.

Schaaf, C.B., Gao, F., Strahler, A.H., Lucht, W., Li, X., Tsang, T., et al., 2002. First operational BRDF albedo, nadir reflectance products from MODIS. Remote Sens. Environ. 83, 135-148.

Simic, A., Chen, J.M., Freemantle, J., Miller, J.R., Pisek, J., 2010. Improving clumping and LAI algorithms based on multi-angle airborne imagery and ground measurements. IEEE Trans. Geosci. Remote Sens. 48 (4), 1742-1759.

Sprintsin, M., Cohen, S., Maseyk, K., Rotenberg, E., Grunzweig, J., Karnieli, A., et al, 2011. Long term and seasonal courses of leaf area index in a semi-arid forest plantation. Agric. For. Meteorol. 151, 565-574.

Verstraete, M.M., Hunt, L.A., Scholes, R.J., Clerici, M., Pinty, B., Nelson, D.L., 2012 Generating 275-m resolution land surface products from the Multi-angle Imaging SpectroRadiometer data. IEEE Trans. Geosci. Remote Sens. 50, 3980-3990.

Weiss, M., Baret, F., Block, T., Koetz, B., Burini, A., Scholze, B., Lecharpentier, P. Brockmann, C., Fernandes, R., Plummer, S., Myneni, R., Gobron, N., Nightingale, J., Schaepman-Strub, G., Camacho, F., Sanchez-Azofeifa, A., 2014. On line validation exercise (OLIVE): a web based service for the validation of medium resolution land products. Application to FAPAR products. Remote Sens. 6, 4190 4216. 